\title{
Morbidity and mortality in stranded Cook Inlet beluga whales Delphinapterus leucas
}

\author{
Kathleen A. Burek-Huntington ${ }^{1, *}$, Jennifer L. Dushane ${ }^{1}$, Caroline E. C. Goertz ${ }^{2}$ \\ Lena N. Measures ${ }^{3}$, Carlos H. Romero ${ }^{4}$, Stephen A. Raverty ${ }^{5}$
}

${ }^{1}$ Alaska Veterinary Pathology Services, 23834 The Clearing Drive, Eagle River, Alaska 99577, USA

${ }^{2}$ The Alaska SeaLife Center, 301 Railway Avenue, Seward, Alaska 99664, USA

${ }^{3}$ Fisheries and Oceans Canada, Maurice Lamontagne Institute, 850, route de la mer, Mont-Joli, Québec G5H 3Z4, Canada

${ }^{4}$ Infectious Diseases and Pathology, College of Veterinary Medicine, University of Florida, Gainesville, Florida 32610, USA

${ }^{5}$ Animal Health Center, British Columbia MAL, Abbotsford, British Columbia V3G 2M3, Canada

\begin{abstract}
The endangered Cook Inlet (Alaska, USA) stock of beluga whales Delphinapterus leucas declined $47 \%$ between 1994 and 1998, from an estimated 653 whales to 347 whales, with a continued decline to approximately 312 in 2012. Between 1998 and 2013, 164 known dead strandings were reported by the National Marine Fisheries Service. Only 38 of these animals, or $23 \%$ of the known stranded carcasses, were necropsied. Carcasses were found between April and October. The majority of animals necropsied were adults $(n=25)$, followed by juveniles $(n=6)$, calves $(n=3)$, and aborted fetuses $(n=4)$. Eight of the 11 mature females were pregnant, post-partum, or lactating. Many $(82 \%)$ of these belugas were in moderate to advanced autolysis, which hampered determination of a cause of death (COD). Each animal had a single primary COD assigned within a broad set of categories. The CODs were unknown $(29 \%)$, trauma $(18 \%)$, perinatal mortality $(13 \%)$, mass stranding $(13 \%)$, single stranding $(11 \%)$, malnutrition $(8 \%)$, or disease $(8 \%)$. Other disease processes were coded as contributory or incidental to COD. Multiple animals had mild to moderate verminous pneumonia due to Stenurus arctomarinus, renal granulomas due to Crassicauda giliakiana, and ulcerative gastritis due to Anisakis sp. Each stranding affords a unique opportunity to obtain natural history data and evidence of human interactions, and, by long-term monitoring, to characterize pathologies of importance to individual and population health.
\end{abstract}

KEY WORDS: Cook Inlet, Alaska $\cdot$ Beluga whale $\cdot$ Delphinapterus leucas $\cdot$ Stranding $\cdot$ Mortality $\cdot$ Morbidity $\cdot$ Stenurus arctomarinus $\cdot$ Crassicauda giliakiana

\section{INTRODUCTION}

Of the 5 stocks of beluga whales Delphinapterus leucas in Alaska (USA) waters, the Cook Inlet (CI) stock is the most genetically isolated (O'CorryCrowe et al. 2002) and probably has been for several thousand years. Early surveys in 1979 estimated a population of 1300 animals (Calkins \& Curatolo 1983). Later surveys documented a $47 \%$ decline in abundance between 1994 (when systematic population surveys began) and 1998, from an estimated 653 to 347 animals (Hobbs et al. 2000). The decline continued to an estimated 312 whales in 2012 (Hobbs et al. 2012). The dramatic decline during the 1990s was originally attributed to unsustainable subsistence harvest levels (Hobbs et al. 2012). As a result, voluntary cessation of hunting was initiated by Alaska Native communities in 1999 and was formalized as a cooperative agreement in 2000 . The population was expected to increase at a rate of 2 to $6 \% \mathrm{yr}^{-1}$; however, surveys indicated a continued decline of about $1.45 \% \mathrm{yr}^{-1}$ from 1999 to 2008 (Hobbs et al. 2012). In 
October 2008, the National Marine Fisheries Service (NMFS) listed CI beluga whales as 'endangered' under the Endangered Species Act (ESA) (73 FR 62919); later, critical habitat was designated for this stock (74 FR 63080, 2 December 2009).

Because this small population has not increased as expected after cessation of subsistence hunting, other factors must be affecting its ability to recover. The Conservation Plan for CI belugas lists potential threats to this population as stranding events, predation, parasitism, disease, and environmental change, among others (NMFS 2008). Necropsies of dead stranded belugas are currently the main source of information about these potential threats.

The physical characteristics of CI influence the ability to observe, report, and respond to strandings. Upper CI is composed of 2 long narrow arms: Turnagain Arm and Knik Arm, with Anchorage, the largest city in Alaska, at their confluence (Fig. 1). Both branches receive significant glacial melt-water, making the water opaque and laden with glacial silt, resulting in the formation of extensive mud flats. The long narrow inlets between mountains result in large tidal exchanges and bore tides (Oey et al. 2007). These extreme tides are strong, fast, and turbulent, containing sufficient energy to capsize small vessels, endanger human life, and strand marine mammals. Other than one major roadway along the northern edge of Turnagain Arm, there is limited vehicular access to the shoreline. Live and dead stranded belugas are reported by small-aircraft pilots, drivers on the highway, wildlife observers, or set-net fishermen. An estimated 205 CI belugas have stranded dead in upper CI since 1988 (NMFS unpublished data), with an average of $8 \mathrm{yr}^{-1}$, ranging from 20 in 2003 to 0 in 1988. Between 1998 and 2013, 164 known dead strandings were reported by the NMFS. Only 38 (23\%) of these stranded animals were necropsied. Here we describe necropsy results from these 38 belugas and discuss implications of these findings relative to conservation measures for CI belugas.

\section{MATERIALS AND METHODS}

\section{Necropsy and sample collection}

Necropsies were performed by a veterinarian with extensive marine mammal experience (C. E. C. Goertz) or board-certified veterinary pathologist (K. A. Burek-Huntington) to determine a cause of death (COD) in addition to collecting a wide variety of samples for contaminants, genetics, diet analysis, life history, histopathology, parasitology, microbiology, virology, and archiving. Carcasses were most often accessed by aircraft, and rarely by road or boat. Data collected from each stranding (Fig. 1) included date, location, sex, and age class. As often as possible, mandibles were collected, and these animals were aged by sectioning teeth and counting growth layer groups (GLGs) (Wainwright \& Walker 1988, HeideJørgensen \& Lockyer 2001), with age equivalent to $1 \mathrm{GLG} \mathrm{yr}^{-1}$ (Stewart et al. 2006). Due to extreme tides and other environmental conditions, mandibles were not always collected, and some collected teeth were not sectioned. Therefore, age class was extrapolated from length data using Vos' (2003) length-age curves. An animal was classified as an aborted fetus when it had a fresh umbilicus, non-inflated lungs, and meconium. Newborn calves were determined by the presence of fetal structures such as an unhealed umbilical cord or a cardiac foramen ovale (Lair et al. 2014). Animals $<2$ yr of age were considered to be calves, females $<7$ yr old and males $<8$ yr old were classified as juveniles, and all other animals were classified as adults, based on reproductive parameters in captive belugas (Robeck et al. 2005). Standard necropsies were performed, and the level of decomposition of carcasses was coded: 2 , fresh; 2.5 , mild; 3 , moderate; 4, advanced decomposition; 5, mummified or skeletonized (Geraci \& Lounsbury 2005). Standard length, axillary girth, blubber thickness, and fluke width were recorded for most animals. Standard

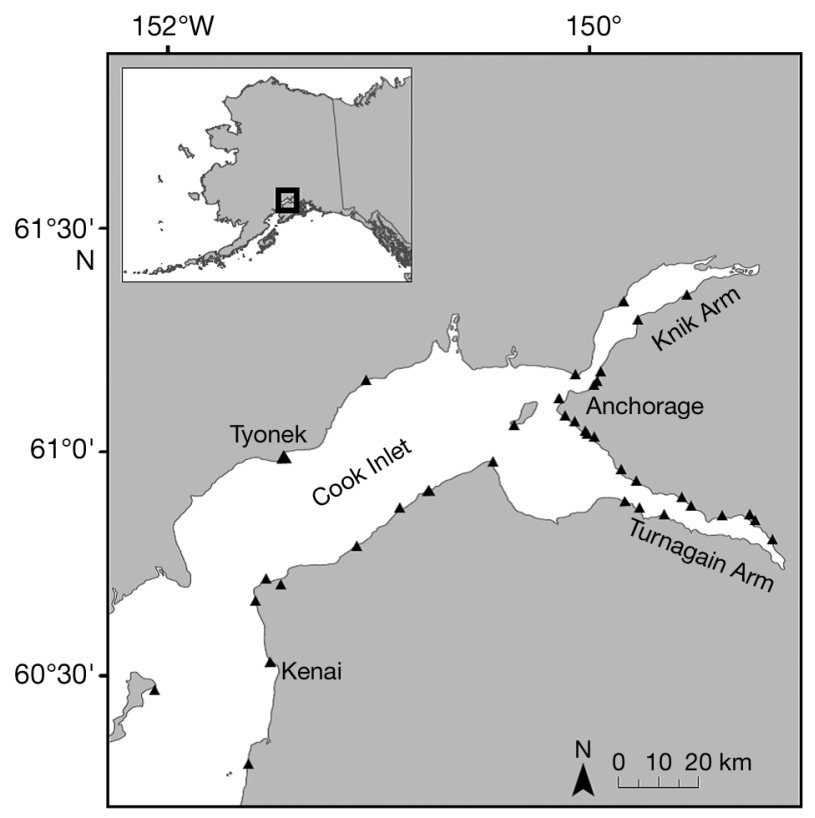

Fig. 1. Distribution of 38 stranded beluga whale Delphinapterus leucas carcasses ( $\mathbf{\Delta}$ ) from Cook Inlet, Alaska, USA 
blubber depth measurements were taken at the axillary region ventral midline, lateral, and dorsal when possible. If these anatomic sites were not accessible, the area measured was documented. When appropriate, tissues were collected for histology and preserved in $10 \%$ neutral buffered formalin, processed at Histology Consulting Services (Pullman, WA), and analyzed by 1 pathologist (K. A. Burek-Huntington).

\section{Ancillary testing}

Ancillary testing was based on the postmortem state, gross observations, and histopathological findings. Most cases were not suitable for bacterial cultures due to postmortem autolysis. In code 2 and 3 cases, select tissues were submitted for aerobic and fecal pathogen culture to Phoenix Laboratories (Everett, WA), the University of California Davis (Davis, CA), or the Animal Health Center (Abbotsford, BC). Ten animals were screened for fecal pathogens including enteric aerobic bacteria as well as Salmonella sp., hemolytic Escherichia coli, Yersinia sp., Plesiomonas sp., Campylobacter sp., Edwardsiella sp., and $\beta$-hemolytic Streptococcus sp. Based on histopathology, a tissue block from case no. 9 (systemic herpesvirus infection) was submitted to the Armed Forces Institute of Pathology for electron microscopy. A variety of parasites preserved in formalin were submitted to Dr. Mike Kinsella (Helm West Laboratory, Missoula, MT) and entire lungs to Fisheries and Oceans Canada (Maurice Lamontagne Institute, Mont-Joli, QC) for extraction and identification of lungworms. Briefly, lungs were partially defrosted and systematically sliced as thin as possible. Slices were allowed to thaw completely in $0.85 \%$ saline solution and then vigorously agitated, and the solution was poured through a series of 3 sieves $(1 \mathrm{~mm}, 500 \mu \mathrm{m}$, and $250 \mu \mathrm{m})$. Contents of each sieve were rinsed into finger bowls and examined using a dissecting microscope. Worms were fixed with hot $10 \%$ glycerin alcohol (1 part glycerol: 9 parts $70 \%$ ethanol), cleared by evaporation of alcohol, and identified by morphology.

When appropriate, polymerase chain reaction (PCR) for Brucella sp. (Casañas et al. 2001) and canine distemper virus (Barrett et al. 1985) was performed at the Abbotsford Animal Health Center (S. A. Raverty). Herpesvirus DNA was assayed by PCR at the University of Florida (C. H. Romero) using degenerate primers (VanDevanter et al. 1996, Ehlers et al. 1999) designed to amplify a region of the DNA polymerase gene that contains highly conserved amino acid motifs within the Herpesviridae. These primers are known to direct the amplification of DNA polymerase gene fragments 215 to 235 base pairs in length for most herpesviruses.

Samples were screened for harmful algal bloom (HAB) biotoxins, specifically domoic acid and saxitoxin, at the Marine Biotoxin Program at the Northwest Fisheries Science Center, using enzyme-linked immunosorbent assays (ELISA) (Lefebvre et al. 2010). Samples tested included urine, stomach contents, feces, serum, milk, amniotic fluid, and abdominal fluid, which were collected and subsequently frozen at $-80^{\circ} \mathrm{C}$. All samples for domoic acid analysis were extracted in $50 \%$ aqueous methanol at a ratio of $4 \mathrm{ml}$ methanol to $1 \mathrm{~g}$ sample. Samples for saxitoxin screening were extracted in $80 \%$ aqueous ethanol at a ratio of $4 \mathrm{ml}$ ethanol to $1 \mathrm{~g}$ sample. Fecal and stomach content extracts were homogenized for at least $60 \mathrm{~s}$, and urine, serum, milk, amniotic fluid, and abdominal fluid extracts were sonicated for at least $45 \mathrm{~s}$. Extracts were then centrifuged at $10000 \times g(20$ $\min$ at $4^{\circ} \mathrm{C}$ ). The supernatant was filtered and samples were stored at $4^{\circ} \mathrm{C}$ until analysis, typically within 1 to $3 \mathrm{~d}$ after extraction. Domoic acid quantification was carried out using Biosense ${ }^{\circledR}$ ELISA (Biosense ${ }^{\circledR}$ Laboratories), and saxitoxin was quantified using Abraxis ELISA kits (Abraxis LLC) according to the manufacturers' instructions, with modifications made to the minimum extract dilutions to avoid matrix effects (Costa et al. 2009, Lefebvre et al. 2010).

\section{COD}

Postmortem findings were compiled and final reports were generated by the lead pathologist (K. A. Burek-Huntington). Morphological diagnoses and laboratory findings were independently reviewed by a second pathologist (S. A. Raverty) and clinician (C. E. C. Goertz). The COD was defined as the condition most likely to have resulted in the animal's stranding and/or death (Bogomolni et al. 2010) and was assigned into diagnostic categories, including (1) unknown: COD could not be determined; (2) perinatal mortality: fetus or neonatal calf mortality of unspecified cause; (3) mass stranding-no significant findings (MS-NSF): assigned when a carcass was found shortly after an observed live mass stranding event; (4) single stranding-no significant findings (SS-NSF): this designation was only used as COD when the carcass condition was sufficiently fresh to rule out other causes of mortality other than the presumed physical and physiological stress associated 
with a live stranding; (5) trauma: findings consistent with blunt or sharp injury significant enough to cause or contribute to death; asphyxiation was also placed into this category as well as human interactions such as possible boat strikes and fisheries interactions; (6) malnutrition: generalized starvation or emaciation, characterized by diminished epaxial muscle fullness and a thin blubber layer; and (7) disease: infectious and degenerative processes. Diagnostic findings not assigned as a primary cause of death were categorized as contributory or incidental and were classified in the same COD categories.

\section{RESULTS}

Between 1998 and 2013, 16 beluga carcasses from Turnagain Arm, 11 from Knik Arm, and 11 from upper CI were necropsied (Fig. 1). Age, sex, carcass code, morphometrics, CODs, contributory, and incidental findings are provided in Table 1. COD categories by age class are summarized in Table 2, and distribution by year is shown in Fig. 2. The majority ( $66 \%$ ) of cases were adults. There were 16 females, 18 males, and 4 animals of unknown sex (Table 1). Based on gross observations of the reproductive tracts, 8 of 11 mature females presented signs of recent or current reproduction: 4 were pregnant, 3 were post-partum, and 1 was lactating. The year 2008 was unusual (Fig. 2) in that it had the most strandings, 4 of which were fetuses, and 2 of the 3 stranded adult females were either pregnant or lactating. No other age or reproductive categories predominated in specific years throughout the course of the study.

Of the 38 examined whales, 7 (18\%) were coded as fresh or mild decomposition (code 2 or 2.5), 13 (34\%) as moderate (code 3$), 17$ (45\%) as advanced (code 4 ), and $1(3 \%)$ as mummified (code 5). Since the majority of belugas were in a moderate to advanced state of decomposition, the diagnostic options were limited. Histopathological analysis was conducted in 33 cases. General microbiological analysis was performed on tissues from 13 animals, fecal pathogens in 10, and biotoxin screening in 18.

\section{Unknown CODs}

In 11 cases $(29 \%)$, advanced autolysis precluded determination of a primary COD. In some of these cases, verminous pneumonia, glacial silt aspiration deep into the airways, and renal parasitism were considered contributory to mortality. Glacial silt was aspirated and formed dense castes of the airways deep into the terminal bronchioles and peripherally to the visceral pleura. This airway foreign matter was commonly observed in this COD category, including some animals that died following known live strandings. While foreign matter can enter upper airways in a carcass rolling in the surf, the degree and depth of penetration in the lungs suggests aspiration by an animal actively and forcefully inspiring. Approximately half of the stranded belugas with a diagnosis of unknown CODs occurred in 2007 (Fig. 2), which corresponded to the second highest stranding mortality rate recorded (NMFS 2008). All of the 11 whales with unknown COD were mature and in good nutritional condition.

\section{Trauma}

Trauma was the COD in 7 cases $(18 \%$; Table 2$)$. Based on field observations and rake marks, 2 were attributed to killer whale Orcinus orca interactions and another was considered a possible killer whale attack with suggestive large, arched defects in the blubber and muscle (case 35). Two were blunt force trauma which could be due to killer whale attack, conspecific aggression, or boat strike, and 1 was an adult male in good nutritional condition that died due to choking on a large starry flounder Platichthys stellatus, which was positioned transversely in the esophagus around the larynx with spines embedded into the surrounding tissues. Trauma due to human interactions was a minor factor in this case series, with only 1 animal found in a set net. This young animal had multiple significant disease processes (Table 1), little evidence of struggle within the net, and massive pulmonary edema indicative of drowning as the immediate cause of death. An old propeller scar was coded as incidental trauma in another adult of unknown sex.

\section{Perinatal mortalities}

Perinatal mortality was the COD in 5 cases $(13 \%$; Table 2): 4 aborted fetuses recovered in 2008 and 1 neonatal calf in 2007. The cause of the abortion and neonatal mortality could not be determined. Placenta to establish disease at the fetal-maternal interface was not available for any of the 4 fetuses. Only 1 fetus had tissues suitable for aerobic cultures, Brucella sp., and morbillivirus PCR, all of which were negative. A frag- 


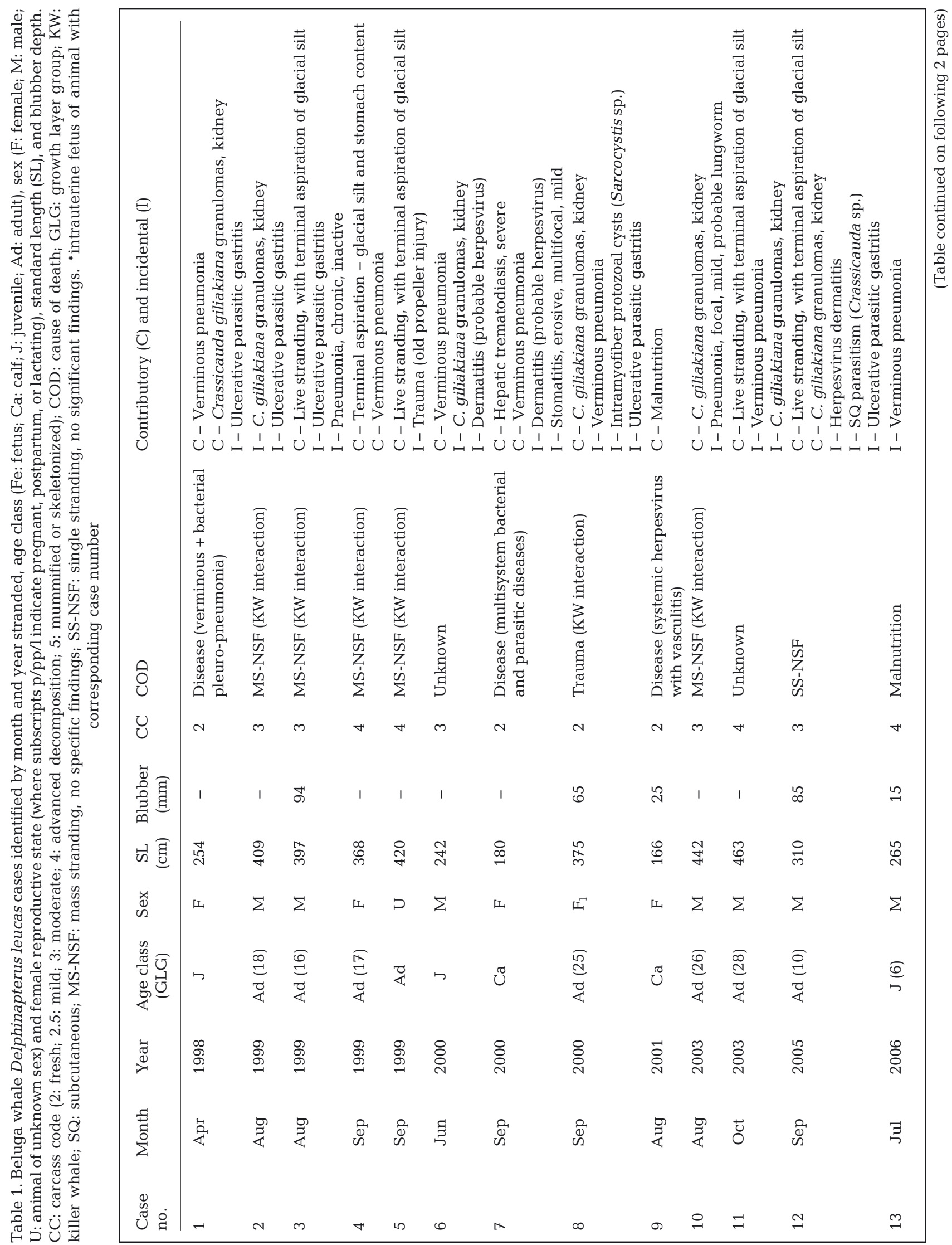




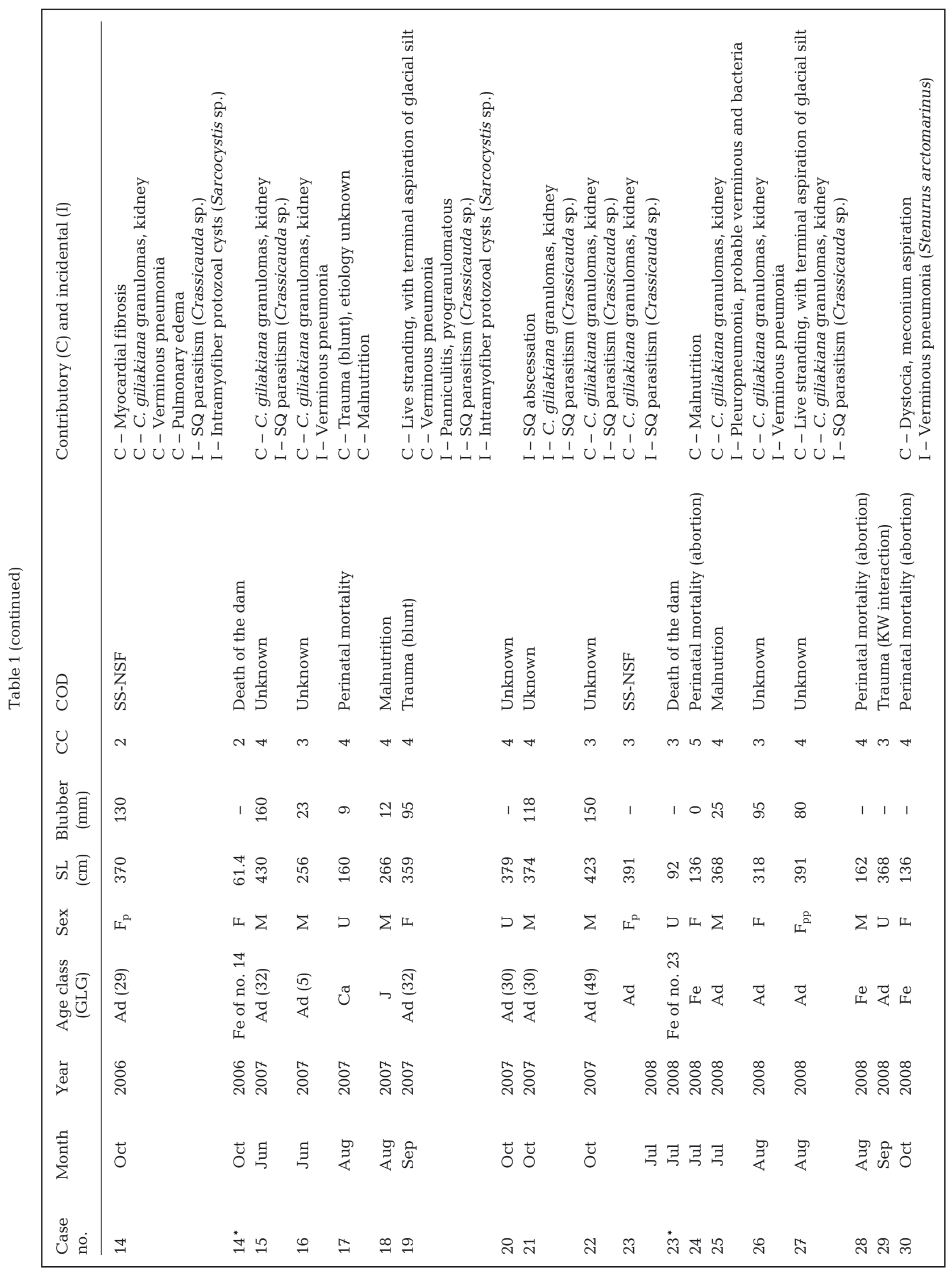




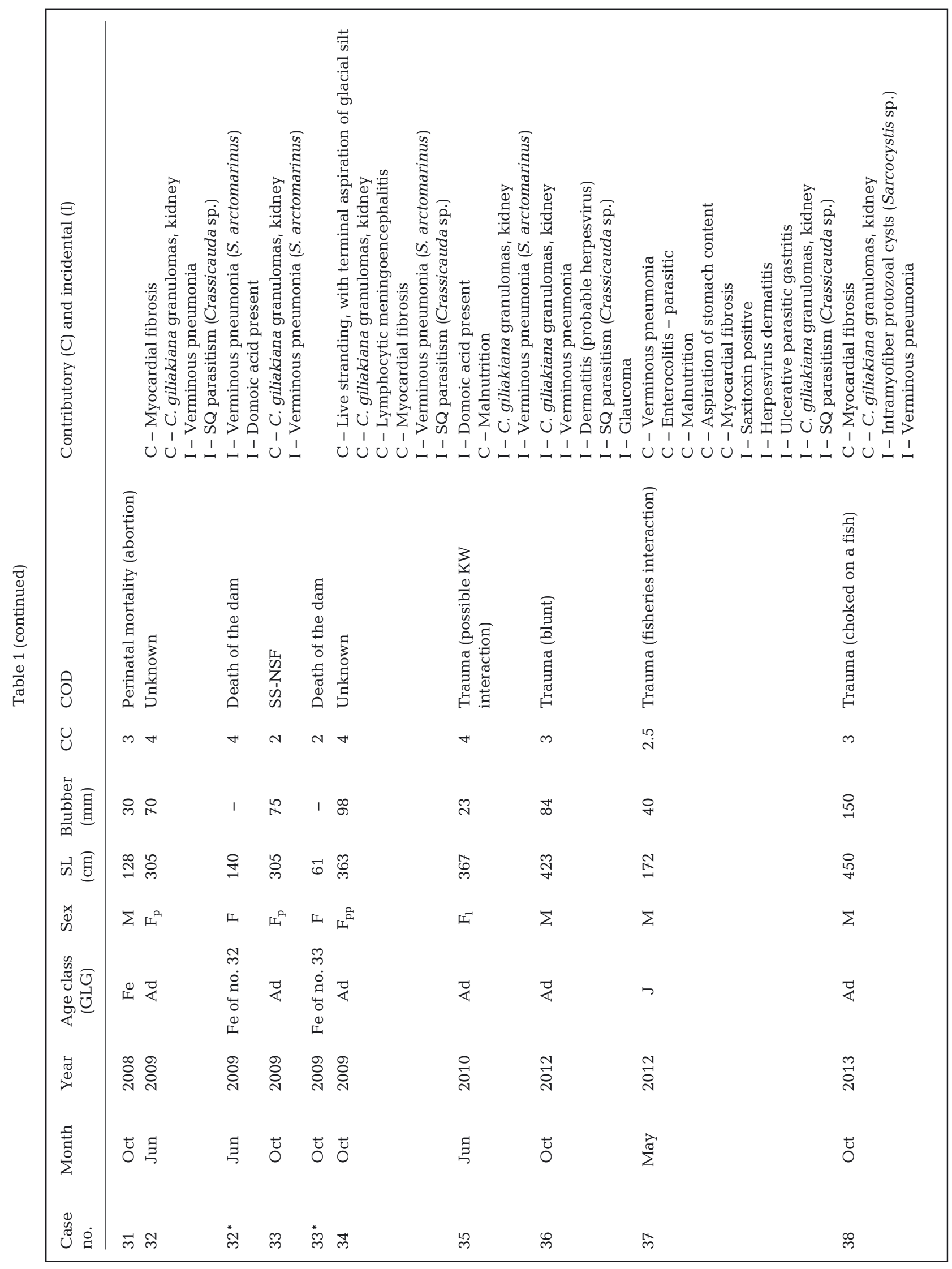


Table 2. Number of stranded Cook Inlet (Alaska, USA) beluga whales Delphinapterus leucas by cause of death (COD) and age (Ad: adult; J: juvenile; Ca: calf; Fe: fetus). MS-NSF: mass stranding, no significant findings; SS-NSF: single stranding, no significant findings

\begin{tabular}{|lcccrrr|}
\hline $\begin{array}{l}\text { Diagnostic } \\
\text { category }\end{array}$ & Ad & $\mathrm{J}$ & $\mathrm{Ca}$ & $\mathrm{Fe}$ & Total & $\begin{array}{r}\% \text { of } \\
\text { total }\end{array}$ \\
\hline Unknown & 9 & 2 & & & 11 & 29 \\
Trauma & 6 & 1 & & & 7 & 18 \\
Perinatal & & & 1 & 4 & 5 & 13 \\
$\quad$ mortality & & & & & 5 & 13 \\
MS-NSF & 5 & & & & 4 & 11 \\
SS-NSF & 4 & & & & 3 & 8 \\
Nutritional & 1 & 2 & & & 3 & 8 \\
Disease & & 1 & 2 & & 38 & 100 \\
Total & 25 & 6 & 3 & 4 & 38 \\
& & & & & & \\
\hline
\end{tabular}

ment of lungworm was found in one of the fetuses and was considered to be incidental to the abortion. The neonatal calf was in poor body condition based on lack of blubber, and had blunt force trauma, both of which were considered contributory to the mortality. A fragment of lungworm was also found in this calf.

\section{MS-NSF}

Five animals (13\%; Table 2$)$ were assigned a COD of MS-NSF. Four of these whales were found dead

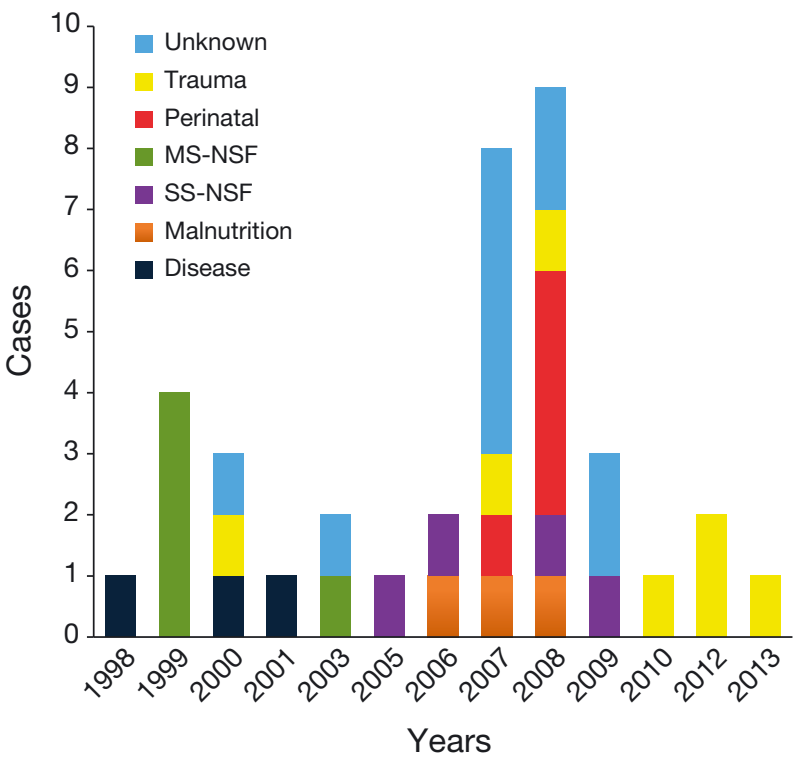

Fig. 2. Distribution of beluga whale Delphinapterus leucas necropsy cases by year and cause of death category. MSNSF: mass stranding, no significant findings; SS-NSF: single stranding, no significant findings shortly after mass live strandings in 1999 (Shelden et al. 2003), and case 10 was found in 2003 following killer whale interactions (Vos et al. 2005).

\section{SS-NSF}

Four whales (11\%; Table 2$)$ were classified as SSNSF. These cases had extensive diagnostic analyses, including histopathology, with infectious disease screening and biotoxin analyses. No significant diagnostic findings were identified to explain the stranding of any of these animals except the expected cardiovascular findings associated with the physical challenge of stranding, such as severe generalized organ congestion. Large amounts of foreign matter were present in the airways of 2 of the 4 belugas, suggesting terminal aspiration of glacial silt, water, or gastric contents as the COD during a live stranding. Three of the MS-NSF, 2 trauma, and 3 unknown COD animals also had this large amount of foreign material consistent with glacial silt in the airways. SS-NSF COD belugas lacked any general temporal stranding pattern (Fig. 2).

\section{Malnutrition}

Eight cases $(21 \%$; Table 2$)$ had malnutrition as the COD $(n=3)$ or contributory to death $(n=5)$. Malnutrition COD cases included 1 adult and 2 juveniles, all of which were male. The 5 cases with malnutrition as a contributory factor included a fetus with a minimal blubber layer, a calf with systemic herpesvirus infection, another possibly abandoned neonatal calf in poor body condition with signs of blunt trauma, a post-partum female, and a juvenile with severe multiple infectious diseases that was caught in a net.

\section{Disease}

Infectious disease was the COD in 3 cases $(8 \%$; Table 2); 1 case (no. 9; Table 1) involved a very thin female calf with multisystemic herpesvirus vasculitis and multifocal necrosis in the adrenal gland (Fig. 3), reproductive tissue, spleen, lymph nodes, skin, and heart muscle. Distinct intranuclear inclusion bodies and margination of the chromatin were evident in adrenal cortical cells adjacent to vascular lesions (Fig. 3b,c). Electron microscopy confirmed the presence of herpesvirus-like particles in the adrenal gland (Fig. 3d). The other 2 cases were both young 
Fig. 3. Herpesvirus infection in adrenal gland of Cook Inlet (Alaska, USA) beluga Delphinapterus leucas. (a) Vasculitis is characterized by pyknotic and karyorrhectic debris within and surrounding the vessel wall $(\boldsymbol{*})$, as well as deposition of perivascular fibrin (fibrinoid necrosis; arrow). Scale bar $=70 \mu \mathrm{m}$. (b) Focal necrosis with scattered cortical cells containing eosinophilic intranuclear inclusion bodies (arrow). Scale bar $=70 \mu \mathrm{m}$. (c) Higher magnification of the smudged amphophilic intranuclear inclusion bodies (arrows) with marked margination of the chromatin; hematoxylin and eosin stain. Scale bar $=30 \mu \mathrm{m}$. (d) Electron photomicrograph showing multiple intranuclear naked virions, enveloping at the nuclear membrane $(*)$ and margination of the chromatin (arrow). Scale bar $=1000 \mathrm{~nm}$

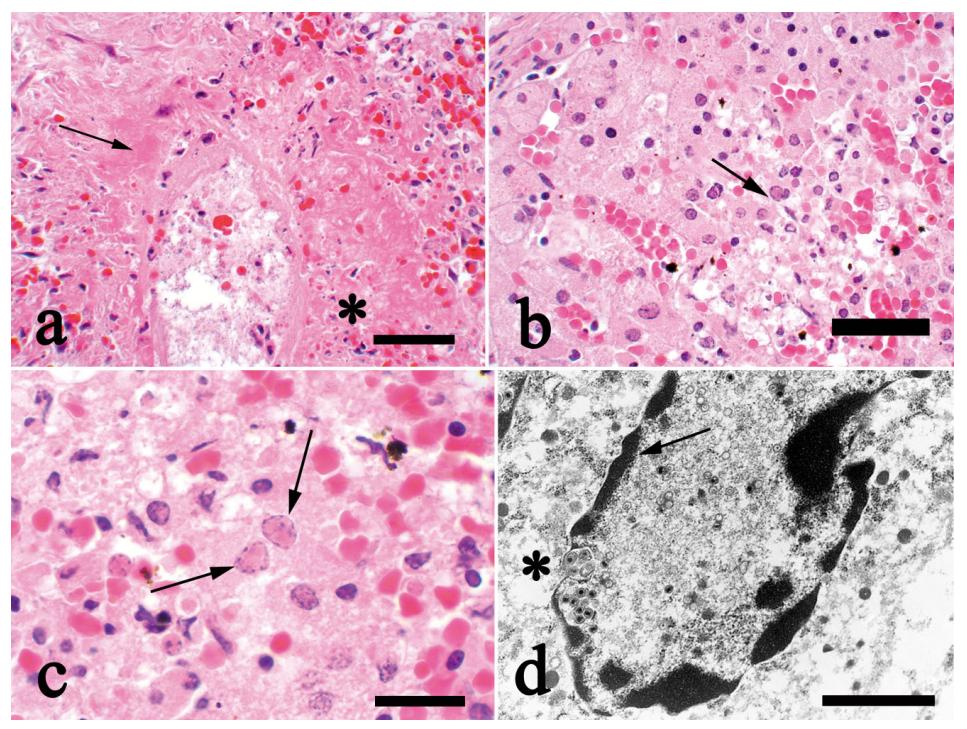

female individuals that died due to multiple mixed bacterial and parasitic diseases. Case 1, a juvenile, had severe bacterial and parasitic pleuropneumonia, and renal crassicaudiasis with extensive tissue destruction. Case 7 was a calf with severe verminous and bacterial pneumonia, hepatobiliary trematodiasis, ulcerative dermatitis, and glossitis of unconfirmed etiology but suggestive of herpesvirus. This was the only case of hepatic trematodiasis identified in this case series and the parasite was not identified. No tissues were available for bacterial cultures in these cases.

Table 3. Lesions and infections in stranded Cook Inlet (Alaska, USA) beluga whales Delphinapterus leucas and their significance with respect to cause of death (COD), contributory $(\mathrm{C})$, or incidental (I)

\begin{tabular}{|lcccc|}
\hline & COD & C & I & Total \\
\hline Mixed systemic disease & 2 & - & - & 2 \\
Virus & & & & \\
$\quad$ Systemic herpes & 1 & - & - & 1 \\
$\quad$ Dermatitis - herpes and & - & - & 5 & 5 \\
$\quad$ unknown & & & & \\
Parasites & - & 16 & 7 & 23 \\
$\quad$ Kidney nematodes & - & 7 & 14 & 21 \\
Lung nematodes & - & 1 & 6 & 7 \\
Gastrointestinal parasites & - & 1 & - & 1 \\
Hepatic trematodes & - & - & 12 & 12 \\
$\quad$ Blubber nematodes & - & - & 4 & 4 \\
Intramuscular protozoa & & & & \\
Undetermined cause & - & 3 & 2 & 5 \\
$\quad$ Myocardial fibrosis & - & - & 2 & 2 \\
Pulmonary fibrosis & - & 1 & - & 1 \\
Lymphocytic encephalitis & - & - & 1 & 1 \\
$\quad$ Steatitis & 4 & 29 & 53 & 85 \\
Total & & & & \\
\hline
\end{tabular}

Parasites

Based on the extent of tissue involvement and associated host response, various parasitic infections were designated as contributory or incidental findings in stranded beluga whales (Table 3). Moderate cases of verminous pneumonia were interpreted to be contributory and mild cases were incidental. Twenty-one animals had gross or histopathological lesions due to lungworms, the majority of which (14) were considered incidental infections. Cases included 1 intrauterine fetus, 1 calf, 5 juveniles, and 14 adults. The gross appearance of moderate lungworm infections was characterized as numerous small (1-2 mm), hard, subpleural nodules generally without grossly evident

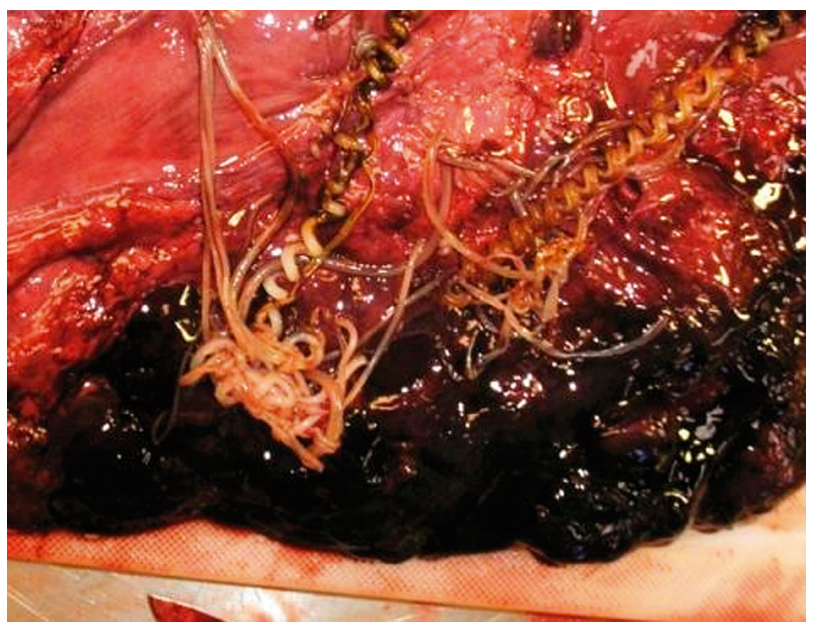

Fig. 4. Crassicauda giliakiana in the kidney of a Cook Inlet (Alaska, USA) beluga whale Delphinapterus leucas 
adult lungworms; in mild infections, lesions were only detected microscopically. Histopathology of moderate infections revealed sections of degenerate parasites with intense mixed inflammatory cells and SplendoreHoeppli type bodies lining the bronchial mucosa. In 5 of 7 cases examined, the lungworms were identified as Stenurus arctomarinus.

Renal nematode infections due to Crassicauda giliakiana were diagnosed in 23 of 31 (74\%) belugas in which kidneys were examined critically (Table 3). Twenty were adults and 3 were juveniles. None of the calves or fetuses were infected. These parasites were encapsulated, forming parasitic granulomas up to $3 \mathrm{~cm}$ in diameter in the cortex of the kidney with highly coiled bodies and the tails of the nematodes extending into the renal calyxes and pelvis (Fig. 4). In chronically affected animals, the capsules were ossified and replaced extensive portions of the kidney tissue. Infections with $<10$ nodules kidney $^{-1}$ were considered to be mild; 11-30 moderate, and > 30 with significant tissue damage due to parasitic granulomas were considered severe. Mild loads of C. giliakiana were scored as incidental; moderate to severe were scored as contributory.

Incidental parasite infections were observed in a few animals. Anisakis sp. nematodes were found in the stomach with ulceration but no observed perforations in 6 animals. Crassicauda sp. (M. Kinsella pers. comm.) were found at the fascia-blubber interface often adjacent to the mammary gland in 12 of the cases and were characterized by fibrogranulomatous inflammation encapsulating coiled and often mineralized nematode parasites. Incidental intramyofiber protozoa consistent with Sarcocystis sp. were detected microscopically in 4 animals.

\section{Bacteria}

Lesions indicative of a bacterial infection in CI belugas included septicemia, pneumonia, and lung abscessation with intralesional bacteria. The extent of postmortem decomposition and bacterial overgrowth precluded microbiological analyses in many cases; however, intralesional bacteria were evident on histopathology in these cases. In cases where tissues were cultured $(\mathrm{n}=14)$, isolated bacteria were consistent with postmortem overgrowth rather than primary pathogens, and there was no associated inflammatory infiltrate within examined histological sections. Bacteria cultured included 1 isolate each of Acinetobacter sp., Citrobacter freundii, Edwardsiella tarda, Morganella sp., Streptococcus viridans, Plesiomonas sp., and Vibrio parahaemolyticus. Aeromonas sp. and Lactobacillus sp. were isolated in 2 cases each; and Enterococcus sp., Escherichia coli, and Proteus sp. in 3 cases each. Ten animals were tested for a panel of fecal pathogens. No Salmonella sp., Clostridium difficile, Campylobacter sp., hemolytic E. coli, or Yersinia sp. were detected. There were 3 animals each with Plesiomonas sp., Proteus sp., and Edwardsiella sp. Isolated enteric aerobic bacteria included Morganella sp. and Enterococcus sp. (1 case each), Aeromonas sp., and Lactobacillus sp. (2 cases each). Tissues from 12 animals were tested for Brucella sp. by PCR and were negative.

\section{Viruses}

One calf died of systemic herpesviral infection as mentioned above. Two juvenile males had dermatitis with punctate, crater-like ulcers, with histopathology of the skin consistent with herpesvirus, which was confirmed by PCR. An alphaherpesvirus isolate was also cultured from the blowhole of case 37, and is currently being characterized (O. Nielsen pers. comm.). There were also 3 other cases with gross lesions consistent with herpesviral infection that could not be confirmed by PCR and lacked convincing inclusions. In another beluga with mild lymphocytic encephalitis, herpesvirus infection was suspected but not confirmed. Representative tissues from 14 animals tested for influenza $(\mathrm{n}=2)$ or morbillivirus $(\mathrm{n}=12)$ by PCR were negative, and lesions suggestive of these diseases were not observed on histopathology.

\section{HAB biotoxins}

Domoic acid and saxitoxin analyses were conducted on tissues from 17 and 15 animals, respectively. Domoic acid was present in 2 out of 17 animals: 1 intrauterine fetus and 1 juvenile that died of trauma. These positives were at very low levels (4.8 and $7.0 \mathrm{ng} \mathrm{ml}^{-1}$ ), which are most likely clinically insignificant. Saxitoxin was present in the feces of 1 animal out of the 15 tested at a level of $3.6 \mathrm{ng} \mathrm{g^{-1 }}$, or just above detection. This animal drowned in a set net and also had extensive other inflammatory processes.

\section{Degenerative}

Five animals, including 1 juvenile male, 1 adult male, and 3 adult females, had heart lesions cha- 
racterized by myocardial degeneration, interfiber edema, and fibrosis. Myocardial degeneration was characterized by patches of myofibers with mild anisocytosis, with many small angular fibers separated by variable amounts of collagen. None of the cases were severe enough to be COD.

\section{DISCUSSION}

Cetaceans strand and die due to various etiologies (Geraci \& Lounsbury 2005), a number of which were observed in this study and which are potentially affecting CI belugas. Many of the CODs reported here remain undetermined due to postmortem decomposition. Reducing the number of unknown CODs is a great challenge, but increased public awareness and reporting of carcasses through the NMFS stranding hotline; additional resources for response such as boats, aircraft, and 4-wheel drive vehicles; and overflights after extreme tides would help to detect and respond rapidly to stranded fresh carcasses, enhancing diagnostic capabilities and accuracy. Radio or satellite tagging and sampling of live-stranded animals would permit health assessment and better characterization of mortality due to live stranding, and would also detect mortalities more quickly. Greater use of molecular diagnostic techniques may increase the ability to detect pathogens since these methods can be useful when dealing with decomposed tissues versus culture-based methods.

In this case series, loss of pregnant and postpartum females is of particular concern in such a small population. Three females of reproductive age and all 4 aborted fetuses died in 2008. This increase in a year in abortions suggests an infectious cause, although maternal nutrition, age, or experience, or environmental factors cannot be discounted. No cause of death was determined in the 4 aborted fetuses and 1 young neonatal calf coded as perinatal mortality. Pathogens known to cause abortion in other marine mammal species were not detected in these cases or from 3 in utero fetuses from stranded dams. However, due to advanced decomposition, it is possible that pathogens were present but not detectable due to postmortem overgrowth, putrefaction, or inherent limitations with sample or test analyses. Pathogens causing mortality and reproductive pathologies include influenza virus, Leptospira sp., Brucella sp. (B. cetacea), cetacean morbillivirus, herpesvirus, and other diseases associated with abortion and early neonatal mortality (Gaydos et al. 2004).
Large animals, particularly pregnant and postpartum females, are over-represented in our study. This may be due to their higher mortality following live stranding compared with small animals, but the paucity of cases precludes conclusions. The vast majority of these cases (66\%) were adult animals, and 8 out of the 11 stranded adult female CI belugas presented with evidence of recent or active reproduction. Some of these animals were relatively fresh and had thorough disease screening, so the most likely CODs were cardiovascular stresses and other pathologies associated with the stranding itself, such as aspiration of foreign matter. Belugas are known to ground themselves intentionally during molting (Smith et al. 1992) and may use stranding to avoid predators such as killer whales (Shelden et al. 2003). They appear able to tolerate brief periods of stranding. However, large animals, especially pregnant females, without the benefit of buoyancy in water may suffer cardiovascular dysfunction due to compression of the chest cavity and thermo-regulatory problems which can then proceed to shock and death (Geraci \& Lounsbury 2005).

Trauma was the COD in 7 cases (18\%), of which 2 were related to killer whale interactions and 3 featured gross lesions consistent with blunt trauma from an unknown source which could be either killer whale or boat strike. Several of the mass strandings were also related to killer whale interactions. In CI, Shelden et al. (2003) suggested that killer whales kill an average of 1 beluga $\mathrm{yr}^{-1}$. Continued monitoring of killer whale-beluga interactions is needed to determine the frequency of killer whale predation events and what effect they might have on population recovery. There was only 1 case of trauma due to human activities, viz. a fishery net entanglement of an already ill individual. This case series may underestimate trauma due to human activities, as the proportion of animals examined at necropsy was small and photo ID studies have documented several live CI belugas with propeller injuries (Kaplan et al. 2009).

Eight belugas in poor nutritional condition were examined at necropsy, with malnutrition considered the COD or contributory to death. One of the contributory cases involved a fetus with no measurable blubber layer, implying in utero malnutrition, presumably related to the poor nutritional status of the dam in the latter stages of pregnancy. Cases in which malnutrition was coded as COD corresponded to individual animals in 2006 to 2008. Determining nutritional state with confidence is problematic. Protocols have been added to our necropsy procedure to obtain objective measures of body condition, includ- 
ing measurements of blubber thickness in standard locations, analysis for percent lipid in the blubber, and weight of the epaxial muscles over lumbar vertebrae (S. Lair pers. comm.). Nevertheless, several animals in later years had poor body condition based on subjective evaluations.

CI belugas rely heavily on salmonids, eulachon Thaleichthys pacificus, and other fish and invertebrates for their prey. There are major commercial fisheries for sockeye salmon, and sport, set-net, and dip-net fisheries for a variety of species throughout the inlet (Moore et al. 2000, ADFG 2012), all of which could potentially change prey availability for CI beluga whales. Alaska Natives have expressed concern over reports of declining fish runs and the potential negative effect this may have on the CI beluga population (Huntington 2000). Since 1990, commercial fisheries for sockeye salmon, as well as sport fisheries for chinook and coho salmon, have reported declines in a number of fish runs in upper CI (Rutz \& Sweet 2000, ADFG 2012). Between 2006 and 2008, harvests of sockeye salmon were the lowest for the $10 \mathrm{yr}$ period between 2002 and 2012 (Dupuis \& Willette 2014). Coordinated research is needed to correlate beluga occurrence with the abundance, distribution, and availability of potential prey (Moore et al. 2000). In addition to competition with fisheries, environmental changes may also affect beluga growth and condition (Harwood et al. 2014) and also need to be correlated with mortality events and the continued decline.

Other causes of poor nutritional condition include preexisting diseases and pathogens. All wild animal populations have pathogens, including viruses, bacteria, fungi, and parasites, many of which have little effect on overall health and survival. Determining which are significant at the population level is challenging, as effects of pathogens can vary with environmental and host factors (Daszak et al. 2000). In long-lived species, infectious diseases affecting fecundity or reproductive success and juvenile survival can have profound population effects (Holmes 1982). In this study, diseases were identified as a COD or a contributing factor in 32 CI beluga cases and included viral, bacterial, degenerative, and parasitic diseases. Using histopathological methods, infectious disease can easily be missed in decomposed carcasses and is likely underrepresented in this case series.

Parasitic infections were noted in lungs and kidneys of many examined CI belugas and, in those cases with moderate infections or extensive inflammation and necrosis, likely contributed to morbidity and mortality. In CI belugas, moderate to mild lesions due to lungworms were a relatively common finding. Stenurus arctomarinus was identified in 5 cases. It is likely that in belugas experiencing the significant cardiovascular and respiratory stresses of being live stranded, moderate lesions due to lungworms contribute to mortality, but in these animals it did not appear to be the primary COD. Pulmonary nematodes reported in belugas in other populations include S. arctomarinus, Halocercus monoceris, and possibly $H$. taurica (Measures 2001). Lungworm infections of $H$. monoceris and $S$. arctomarinus either alone or in combination with bacterial involvement have been identified as a significant cause of mortality, particularly in young St. Lawrence Estuary (SLE) beluga whales (Lair et al. 2014), threatening recruitment and recovery of this population.

Hunter-killed animals in Point Hope and Point Lay, Alaska, had gross evidence of pulmonary nematode infection (14 [56\%] of 25 belugas examined from both villages), with higher prevalence of infection (85\%) in animals from Point Hope than those from Point Lay (38\%). However, Point Lay belugas had more nodular lesions associated with parasites (Woshner et al. 2001). Lungworms were not identified to genus and species. These animals were otherwise healthy and were killed during the hunt, suggesting that low to moderate infections are part of the normal parasitic fauna. S. arctomarinus appears restricted to belugas (Measures 2001) and has not previously been reported in Alaska (Measures et al. 1995); thus Alaska is a new geographic locality for S. arctomarinus. Although the mode of transmission of these parasites is unknown, finding $S$. arctomarinus in a fetus in this study indicates that transplacental transmission may also occur as has been suggested for $H$. lagenorhynchi in bottlenose dolphins Tursiops truncatus (Dailey et al. 1991).

The majority of animals in this study had Crassicauda giliakiana parasitic granulomas in the kidney, with some animals having numerous granulomas. This parasite has been reported in beluga stocks in the Sea of Okhotsk, North Pacific Ocean, and Amur River, but not in Alaska beluga whales (Measures et al. 1995). CI is thus a new geographic location for this parasite. In an unpublished case series of hunterharvested belugas from Point Lay, Point Hope, Barrow, and Kaktovik, Alaska, only 1 animal out of 19 examined carried this parasite (T. O'Hara and V. Woshner pers. comm.). Similar lesions have not been documented in SLE belugas (Martineau et al. 1988, De Guise et al. 1995, Lair et al. 2014), and only 1 presumptive occurrence has been documented in a 
hunter-harvested adult beluga examined near the Mackenzie Delta, Northwest Territories (Canada; S. A. Raverty pers. obs.). These parasites have also been described in a Cuvier's beaked whale Ziphius cavirostris (Kikuchi et al. 1995) and a Baird's beaked whale Berardius bairdii (Araki et al. 1994).

While extensive damage to and loss of renal parenchyma has been documented in some CI belugas, this parasite presumably does not impede normal kidney function, since $2 / 3$ to $3 / 4$ of renal tissue must be lost before renal insufficiency and failure occur (Alpers 2010). Clinical chemistries and aqueous humor analysis (Coe 1993) may be useful in assessing renal function in live or fresh dead animals. The life cycle of C. giliakiana is unknown but, as in other spirurid nematodes, Crassicauda eggs are thickshelled and larvated when shed. Spirurids typically use arthropod intermediate hosts, and in the marine environment crustaceans such as copepods or krill may be involved in horizontal transmission (Anderson 2000). A related nematode, C. boopis, also has a renal tropism and can affect the cardiovascular system in large baleen whales, particularly fin whales. Adult C. boopis are present in the kidneys of some neonates, suggesting that vertical transmission may occur and thus may affect recruitment due to mortality of infected juvenile fin whales (Lambertsen 1986, 1992). C. giliakiana has not been detected in fetuses or young CI belugas.

In CI belugas, incidental parasite infections included gastric Anisakis sp. with no associated lesions, myocellular protozoa consistent with Sarcocystis spp., and hypodermal Crassicauda sp. (M. Kinsella pers. comm.). One case of severe cholangiohepatitis due to liver flukes diagnosed in a CI beluga was thought to be contributory to COD. Endoparasites reported in other beluga populations include gastrointestinal nematodes or roundworms (Contracaecum sp., A. simplex; Klinkhart 1966, Wazura et al. 1986, Measures et al. 1995), trematodes or flukes (Synthesium [syn. Hadwenius] seymouri; Wazura et al. 1986, Lair et al. 2014), and protozoa (Toxoplasma gondii and Sarcocystis sp.; De Guise et al. 1993, Martineau et al. 1994, Mikaelian et al. 2000).

Bacterial infection is considered a major cause of morbidity and mortality in captive belugas (L. Dunn pers. comm.). A wide diversity of bacterial pathogens are reported in captive animals (Higgins 2000, Bowenkamp et al. 2001). Bacteria implicated in clinical disease and death in SLE belugas are generally found in water with high organic loads (Martineau et al. 2003) and are typically opportunistic, i.e. are normally found in the environment and/or healthy hosts, and cause disease when host immunological defenses are compromised. Chemical contaminants that compromise immunity may also render SLE belugas more susceptible to opportunistic pathogens. A small number of CI belugas were cultured for bacteria. Bacteria detected were considered postmortem contaminants rather than pathogens, due to the lack of inflammatory response on histopathology.

The only virus identified in CI belugas was a herpesvirus, which was the COD in 1 case with systemic disease and the cause of ulcerative dermatitis in several others. Cases of ulcerative or proliferative dermatitis and possibly esophageal ulcers due to a herpesvirus have been reported in captive and wild belugas (Martineau et al. 1988, Barr et al. 1989), as well as in several other species of cetaceans including bottlenose dolphins (Manire et al. 2006) and dusky dolphins Lagenorhynchus obscurus (Van Bressem et al. 1994). Recently, a penile lesion positive for a herpesvirus by PCR was described in an SLE beluga (Bellehumeur et al. 2015), disseminated fatal herpesvirus infection was described in an immature female bottlenose dolphin (Blanchard et al. 2001), and fatal herpesviral encephalitis was described in a harbor porpoise Phocoena phocoena (Kennedy et al. 1992). Our report is the first case of fatal disseminated herpesvirus in a beluga, but the significance of this virus for the CI beluga stock is unknown.

Most mammalian species have distinct host-adapted herpesviruses generally causing disease and mortality only in immunosuppressed, debilitated, young, or stressed individuals (Kennedy et al. 1992). Occasionally, herpesviruses infect non-host-adapted species and result in severe fulminant disease (Huff \& Barry 2003). Viral isolates have been obtained from both CI and Bristol Bay belugas, and efforts are currently underway to characterize these viruses. If they are enzootic pathogens, as expected, shedding of these herpesviruses may be a useful bioindicator of stress at the population level or of immunosuppression or debilitation in an individual animal.

CI belugas are unique in Alaska given that their habitat is in close proximity to Anchorage, the largest urban area in Alaska. Alaska has a total human population of 710231 , and over half of the population resides in the drainage system leading into CI beluga habitat (US Census Bureau 2010) and has increased $67 \%$ from 1980 to 2010. CI belugas must also contend with other anthropogenic factors, as Anchorage is a major industrial and maritime traffic center (Moore et al. 2000). Anchorage has only primary treatment of sewage. Although extensive testing for specific chemicals in effluent has been performed at the sewage 
treatment plant (URS Corp 2010), there is no pathogen surveillance (URS Corp 2011). The extreme tidal action is theorized to flush effluents out of CI and dilute any pathogens or pollutants. The effect of residual chemical and biological effluent on belugas is unknown, and proactive and systematic examination of dead stranded carcasses, coupled with molecular studies, microbiology, and toxicology, can offer important insights into the effects of this discharge on the health of CI beluga whales.

Contaminants must be considered as a possible threat to CI beluga health. Previous studies have determined that levels of persistent organic pollutants and heavy metals are relatively low in this population (Becker et al. 2000) compared with the other subarctic populations such as the SLE belugas (Martineau et al. 2003). One possible area of concern was the higher than expected level of hepatic copper, which was substantially higher than reported for Australian bottlenose dolphins $\left(29 \mathrm{mg} \mathrm{kg}^{-1}\right.$; Lavery et al. 2009, URS Corp 2010). The CI beluga hepatic copper levels (162 $\pm 130 \mathrm{mg} \mathrm{kg}^{-1}$ ) overlap that of belugas from Point Lay $\left(61.6 \pm 42.3 \mathrm{mg} \mathrm{kg}^{-1}\right)$ and are consistent with levels in Hudson Bay belugas, all of which are considerably higher than levels in SLE belugas (0.58 $\pm 0.41 \mathrm{mg} \mathrm{kg}^{-1}$; Becker et al. 2000). The sources of such high copper levels are unknown. High copper levels may damage renal tissue and affect blood cell production and immune function. No renal lesions attributable to high levels of copper were observed in this study nor have they been reported elsewhere in belugas.

Polycyclic aromatic hydrocarbons (PAHs) may be a concern in CI belugas due to ongoing and potentially increasing oil and gas production in CI (Calkins \& Curatolo 1983, Moore et al. 2000). The high prevalence of gastrointestinal neoplasia in the SLE belugas has been attributed to PAHs in their environment (Martineau et al. 2003), although this neoplasia has not been obse rved since 2004 (Lair et al. 2014). Comparison between CI and SLE belugas with respect to PAH exposure may be instructive.

Necropsies provide critical insights into the morbidity and mortality trends in populations of marine mammals (Bogomolni et al. 2010). These insights can focus management and research efforts and resources. Mass and single strandings are potentially significant factors in contributing to mortality and declines in this population. As with many other cetacean species, specific causes of strandings remain unknown. In contrast to other cetacean stranding mortality surveys (Martineau et al. 2003, Gaydos et al. 2004, Lair et al. 2014), a disproportionately low number of CODs were attributed to trauma, malnutrition, or infectious disease. Interestingly, infectious CODs were identified early in this study $(1998,2000$, and 2001), whereas perinatal mortality $(2007,2008)$ and malnutrition CODs (2006-2008) occurred more recently. This temporal pattern suggests that there may have been environmental factors involved in this shift in COD (Harwood et al. 2014), but further data are required before any conclusions can be reached.

Better detection of mortalities of CI belugas; resources for necropsies and diagnostics on fresh carcasses; live capture research; assessment of prey abundance, availability, and quality; and monitoring of killer whale interactions may provide valuable insights into the decline of this endangered beluga stock. Furthermore, enhanced efforts to necropsy beach-cast animals in order to determine CODs for a larger proportion of animals are critical to add to our sample size and to detect any trends in mortality and its causes in this endangered beluga population.

Acknowledgements. We thank the many volunteers who have assisted with necropsies over the years, along with Barbara Mahoney and NMFS for support and encouragement. We also thank Preston Kendrick, Dr. Kathi Lefebvre, and Dr. Elizabeth Frame at the Northwest Fisheries Science Center, NOAA Fisheries, for their work in analyzing samples for domoic acid and saxitoxins; Dr. Mike Kinsella for identification of Anisakis; and Dr. Erik Lombardini at The Armed Forces Institute of Pathology for the electron microscopy for the herpesvirus case. This work was funded through NMFS contracts 40AANF804344, DG133F05SE6370, HA133F-07SE-3870, and HA133F-08-SE-4119 and the NOAA John H. Prescott Program awards NA09NMF4390236 and NA12NMF4390162. Samples were collected under permits in collaboration with NMFS, Alaska Region Office, and also as Co-investigator on Marine Mammal Health and Stranding Response Program (MMHSRP) Permit nos. 932-1489-08 through -10 and 932-1905-00/MA-009526.

\section{LITERATURE CITED}

ADFG (Alaska Department of Fish and Game) (2012) Fishing in Alaska. www.adfg.alaska.gov/index.cfm?adfg= fishing.main (accessed June 2014)

Alpers CE (2010) The kidney. In: Kumar V, Abbas AK, Fausto N, Aster JC (eds) Robbins and Cotran pathologic basis of disease, 8th edn. Saunders, Philadelphia, PA, p 905-970

Anderson RC (2000) Nematode parasites of vertebrates: their development and transmission. CABI Publishing, Wallingford

Araki J, Machida M, Kuramochi T (1994) Three species of Crassicauda (Nematoda, Spirurida) from cetaceans in Japanese and adjacent waters. Bull Natl Sci Mus Ser A (Zool) 20:59-65

Barr B, Dunn JL, Daniel MD, Banford A (1989) Herpes-like viral dermatitis in a beluga whale (Delphinapterus leucas). J Wildl Dis 25:608-611 
Barrett T, Shrimpton S, Russell SEH (1985) Nucleotide sequence of the entire protein coding region of canine distemper virus polymerase associated $(\mathrm{P})$ protein mRNA. Virus Res 3:367-372

Becker PR, Krahn MM, Mackey EA, Demiralp R and others (2000) Concentrations of polychlorinated biphenyls (PCB's), chlorinated pesticides, and heavy metals and other elements in tissues of belugas, Delphinapterus leucas, from Cook Inlet, Alaska. Mar Fish Rev 62:81-98

Bellehumeur C, Lair S, Romero CH, Provost C, Nielsen O, Gagnon CA (2015) Identification of a novel herpesvirus associated with a penile proliferative lesion in a beluga (Delphinapterus leucas). J Wildl Dis 51:244-249

Blanchard TW, Santiago NT, Lipscomb TP, Garber RL, McFee WE, Knowles S (2001) Two novel alphaherpesviruses associated with fatal disseminated infections in Atlantic bottlenose dolphins. J Wildl Dis 37:297-305

> Bogomolni AL, Pugliares KR, Sharp SM, Patchett K and others (2010) Mortality trends of stranded marine mammals on Cape Cod and southeastern Massachusetts, USA, 2000 to 2006. Dis Aquat Org 88:143-155

> Bowenkamp KE, Frasca S Jr, Draghi A II, Tsongalis GJ and others (2001) Mycobacterium marinum dermatitis and panniculitis with chronic pleuritis in a captive white whale (Delphinapterus leucas) with aortic rupture. J Vet Diagn Invest 13:524-530

Calkins DG, Curatolo JA (1983) Marine mammals of lower Cook Inlet and the potential for impact from outer continental shelf oil and gas exploration, development and transport. Environmental Assessment of the Alaskan Continental Shelf. Final Reports of the Principal Investigators. US Department of Commerce, NOAA, Juneau, AK

> Casañas MC, Queipo-Ortuño MI, Rodriguez-Torres A, Orduña A, Colmenero JD, Morata P (2001) Specificity of a polymerase chain reaction assay of a target sequence on the 31-kilodalton Brucella antigen DNA used to diagnose human brucellosis. Eur J Clin Microbiol Infect Dis 20:127-131

Coe JI (1993) Postmortem chemistry update: emphasis on forensic application. Am J Forensic Med Pathol 14: 91-117

Costa PR, Baugh KA, Wright B, Ralonde R and others (2009) Comparative determination of paralytic shellfish toxins (PSPs) using five different toxin detection methods in shellfish species collected in the Aleutian Islands, Alaska. Toxicon 54:313-320

> Dailey M, Walsh M, Odell D, Campbell T (1991) Evidence of prenatal infection in the bottlenose dolphin (Tursiops truncatus) with the lungworm Halocercus lagenorhynchi (Nematoda: Pseudallidae). J Wildl Dis 27:164-165

> Daszak P, Cunningham A, Hyatt AD (2000) Emerging infectious diseases of wildlife: threats to biodiversity and human health. Science 287:443-449

De Guise S, Lagacé A, Girard C, Béland P (1993) Intramuscular sarcocystis in two beluga whales and an Atlantic white-sided dolphin from the St. Lawrence Estuary, Quebec, Canada. J Vet Diagn Invest 5:296-300

> De Guise S, Lagacé A, Béland P, Girard C, Higgens R (1995) Non-neoplastic lesions in beluga whales (Delphinapterus leucas) and other marine mammals from the St. Lawrence Estuary. J Comp Pathol 112:257-271

Dupuis AW, Willette TM (2014) Migratory timing and abundance estimates of sockeye salmon into upper Cook Inlet, Alaska, 2012. Fish. Data Series no. 14-25. Alaska Department of Fish and Game, Anchorage, AK
Ehlers B, Borchers K, Grund C, Frolich K, Ludwig H, Buhk HJ (1999) Detection of new DNA polymerase genes of known and potentially novel herpesviruses by PCR with degenerate and deoxyinosine-substituted primers. Virus Genes 18:211-220

Gaydos JK, Balcomb KC, Osborne RW, Dieurauf L (2004) Evaluating potential infectious disease threats for southern resident killer whales, Orcinus orca: a model for endangered species. Biol Conserv 117:253-262

Geraci JR, Lounsbury VJ (2005) Marine mammals ashore: a field guide for strandings, 2nd edn. National Aquarium in Baltimore, Baltimore, MD

> Harwood LA, Kingsley MCS, Smith TG (2014) An emerging pattern of declining growth rates in belugas of the Beaufort Sea: 1989-2008. Arctic 67:483-492

Heide-Jørgensen MP, Lockyer C (2001) Age and sex distributions in the catches of belugas, Delphinapterus leucas, in West Greenland and in western Russia. Mamm Biol 66:215-227

> Higgins R (2000) Bacteria and fungi of marine mammals: a review. Can Vet J 41:105-116

Hobbs RC, Rugh DJ, DeMaster DP (2000) Abundance of beluga whales, Delphinapterus leucas, in Cook Inlet, Alaska, 1994-2000. Mar Fish Rev 62:37-45

Hobbs RC, Sims CL, Shelden KEW (2012) Estimated abundance of belugas in Cook Inlet, Alaska, from aerial surveys conducted in June 2012. NMFS, NMML. https:// alaskafisheries.noaa.gov/protectedresources/whales/ beluga/abundance/2012estimates.pdf

Holmes J (1982) Impact of infectious disease agents on the population growth and geographical distribution of animals. Popul Biol Infect Dis 25:37-51

> Huff JL, Barry PA (2003) B-virus (Cercopithecine herpesvirus 1) infection in humans and macaques: potential for zoonotic disease. Emerg Infect Dis 9:246-250

Huntington HP (2000) Traditional knowledge of the ecology of belugas, Delphinapterus leucas, in Cook Inlet, Alaska. Mar Fish Rev 62:134-140

Kaplan CC, McGuire TL, Blees MK, Raborn SW (2009) Longevity and causes of marks seen on Cook Inlet beluga whales. In: Photo-identification of beluga whales in Upper Cook Inlet, Alaska: mark analysis, mark-resight estimates, and color analysis from photographs taken in 2008. Report prepared by LGL Alaska Research Associates, Inc., Anchorage, AK, for National Fish and Wildlife Foundation, Chevron, and ConocoPhillips Alaska, Inc., p1-ii, 1-32

Kennedy S, Lindstedt IJ, McAliskey MM, McConnell SA, McCollough SJ (1992) Herpesviral encephalitis in a harbor porpoise (Phocoena phocoena). J Zoo Wildl Med 23:374-379

Kikuchi S, Kazuno M, Nakajima M (1995) Morphology of Crassicauda giliakiana (Nematoda; Spirurida) from a Cuvier's beaked whale Ziphius cavirostris. Jpn J Parasitol 44:228-237

Klinkhart EG (1966) The beluga whale in Alaska. Federal Aid in Wildlife Restoration Project Report, Vol. VII, Projects W-6-R and W-14-R. Alaska Department of Fish and Game, Juneau, AK

Lair S, Martineau D, Measures LN (2014) Causes of mortality in St. Lawrence Estuary beluga (Delphinapterus leucas) from 1983 to 2012. Sci Advis Sec Res Doc 2013/ 119. DFO Canada, Ottawa. http://publications.gc.ca/ collections/collection_2014/mpo-dfo/Fs70-5-2013-118eng.pdf 
Lambertsen RH (1986) Disease of the common fin whale (Balaenoptera physalus): crassicaudiosis of the urinary system. J Mammal 67:353-366

Lambertsen RH (1992) Crassicaudosis: a parasitic disease threatening the health and population recovery of large baleen whales. Rev Sci Tech 11:1131-1141

Lavery TJ, Kemper CM, Sanderson K, Schultz CG, Coyle P, Mitchell JG, Seuront L (2009) Heavy metal toxicity of kidney and bone tissues in South Australian adult bottlenose dolphins (Tursiops aduncus). Mar Environ Res 67:1-7

Lefebvre KA, Robertson A, Frame ER, Colegrove KM and others (2010) Clinical signs and histopathology associated with domoic acid poisoning in northern fur seals (Callorhinus ursinus) and comparison of toxin detection methods. Harmful Algae 9:374-383

- Manire CA, Smolarek KA, Romero CH, Kinsel MJ, Clauss TM, Byrd L (2006) Proliferative dermatitis associated with a novel alphaherpesvirus in an Atlantic bottlenose dolphin (Tursiops truncatus). J Zoo Wildl Med 37:174-181

- Martineau D, Lagace A, Beland P, Higgins R, Armstrong D, Shugart LR (1988) Pathology of stranded beluga whales (Delphinapterus leucas) from the St. Lawrence Estuary, Quebec, Canada. J Comp Pathol 98:287-310

Martineau D, De Guise S, Fournier M, Shugart L, Girard C, Lagace A, Beland P (1994) Pathology and toxicology of beluga whales from the St. Lawrence Estuary, Quebec, Canada. Past, present and future. Sci Total Environ 154: 201-215

Martineau D, Mikaelian I, Lapointe JM, Labelle P, Higgins R (2003) Pathology of cetaceans. A case study: beluga from the St. Lawrence Estuary. In: Vos JG, Bossart GD, Fournier M, O'Shea TJ (eds) Toxicology of marine mammals. Taylor \& Francis, London, p 333-380

Measures L (2001) Lungworms in marine mammals. In: Samuel WM, Pybys MJ, Kocan AA (eds) Infectious and parasitic diseases of wild mammals. Iowa State University Press, Ames, IA, p 279-300

> Measures LN, Beland P, Martineau D, De Guise S (1995) Helminths of an endangered population of beluga, Delphinapterus leucas, in the St. Lawrence Estuary, Canada. Can J Zool 73:1402-1409

Mikaelian I, Boisclair J, Dubey JP, Kennedy S, Martineau D (2000) Toxoplasmosis in beluga whales (Delphinapterus leucas) from the St. Lawrence Estuary: two case reports and a serological survey. J Comp Pathol 122:73-76

Moore SE, Shelden KE, Litzky LK, Mahoney BA, Rugh DJ (2000) Beluga, Delphinapterus leucas, habitat associations in Cook Inlet, Alaska. Mar Fish Rev 62:60-80

NMFS (National Marine Fisheries Service) (2008) Conservation plan for the Cook Inlet beluga whale (Delphinapterus leucas). NOAA, NMFS, Juneau, AK

O'Corry-Crowe GM, Dizon AE, Suydam R, Lowry LF (2002) Molecular genetic studies of population structure and movement patterns in a migratory species: the beluga whale, Delphinapterus leucas, in the western nearctic. In: Pfeiffer CJ (ed) Molecular and cell biology of marine mammals. Krieger Publishing Company, Malabar, FL, p 53-64

Editorial responsibility: Michael Moore, Woods Hole, Massachusetts, USA
Oey LY, Ezer T, Hu C, Muller-Karger FE (2007) Baroclinic tidal flows and inundation processes in Cook Inlet, Alaska: numerical modeling and satellite observations. Ocean Dyn 57:205-221

Robeck TR, Monfort SL, Calle PP, Dunn JL and others (2005) Reproduction, growth and development in captive beluga (Delphinapterus leucas). Zoo Biol 24:29-49

Rutz D, Sweet D (2000) Area management report for the recreational fisheries of northern Cook Inlet, 1999. Fish Manag Rep 00-8. Alaska Department of Fish and Game, Anchorage, AK

> Shelden KEW, Rugh DJ, Mahoney BA, Dahlheim ME (2003) Killer whale predation on belugas in Cook Inlet, Alaska: implications for a depleted population. Mar Mamm Sci 19:529-544

Smith TG, St. Aubin DJ, Hammill MO (1992) Rubbing behaviour of belugas, Delphinapterus leucas, in a high Arctic Estuary. Can J Zool 70:2405-2409

Stewart REA, Campana SE, Jones CM, Stewart BE (2006) Bomb radiocarbon dating calibrates beluga (Delphinapterus leucas) age estimates. Can J Zool 84: 1840-1852

URS Corp (2010) Chemical exposures for Cook Inlet beluga whales: a literature review and evaluation. Report prepared for NOAA Fisheries, NMFS, Anchorage, AK

URS Corp (2011) Pathogen exposures for Cook Inlet beluga whales: a supplement to 'Chemical exposure for Cook Inlet beluga whales: a literature review and evaluation.' Report prepared for NOAA Fisheries, NMFS, Anchorage, AK

US Census Bureau (2010) Demographic profile for Alaska. Government Printing Office, Washington, DC. http:// live.laborstats.alaska.gov/cen/dp.cfm (accessed 17 November 2014)

- Van Bressem MF, Van Waerebeek K, Garcia-Godos A, Dekegel D, Pastoret PP (1994) Herpes-like virus in dusky dolphins, Lagenorhynchus obscurus, from coastal Peru. Mar Mamm Sci 10:354-359

VanDevanter DR, Warrener P, Bennett L, Schultz ER, Coulter S, Garber RL, Rose TM (1996) Detection and analysis of diverse herpesviral species by consensus primer PCR. J Clin Microbiol 34:1666-1671

Vos DJ (2003) Cook Inlet beluga age and growth. MSc Thesis, Alaska Pacific University, Anchorage, AK

> Vos DJ, Shelden KEW, Orr JW (2005) Unusual mortality in the depleted Cook Inlet beluga (Delphinapterus leucas) population. Northwest Nat 86:59-65

Wainwright KL, Walker RS (1988) A method for preparing beluga (white whale), D. leucas, teeth for ageing. Can Manuscr Rep Fish Aquat Sci 1967:1-15

> Wazura KW, Strong JT, Glenn CL, Bush AO (1986) Helminths of the beluga whale (Delphinapterus leucas) from the Mackenzie River delta, Northwest Territories. J Wildl Dis 22:440-442

- Woshner VM, O'Hara TM, Bratton GR, Suydam RS, Beasley VR (2001) Concentrations and interactions of selected essential and non-essential elements in bowhead and beluga whales of Arctic Alaska. J Wildl Dis 37:693-710

Submitted: June 27, 2014; Accepted: December 16, 2014

Proofs received from author(s): March 24, 2015 